\title{
FEDERAL CRIMINAL JURISDICTION AND PROSECUTORS' DISCRETION
}

\author{
L. B. ScHWARTZ*
}

National criminal jurisdiction, which now ranges from treason to hunting offenses, occupying approximately one quarter of the federal judges' time, ${ }^{1}$ had its meager beginnings before the birth of constitutional federal government itself. The Articles of Confederation provided that "the United States in Congress assembled, shall have the sole and exclusive right and power of ... appointing courts for the trial of piracies and felonies committed on the high seas. ..."2 The Constitution defined treason and expressly authorized Congress to punish the counterfeiting of United States securities and coins, as well as piracies and felonies on the high seas and offenses against the law of nations. ${ }^{3}$ But the great bulk of federal criminal activity rests upon the constitutional power of Congress to enact laws "necessary and proper" to the execution of specifically conferred powers, for there are no commonlaw crimes in federal jurisprudence. The first federal criminal legislation, antedating

* B.S. 1932, Wharton School, University of Pennsylvania; LL.B. 1935, University of Pennsylvania. Assistant Professor of Law, University of Pennsylvania. General Counsel's Office, Securitics and Exchange Commission, 1935-39; United States Department of Justice, Criminal and Antitrust Divisions, 1939-46. The author acknowledges the able assistance of W. T. Darmopray, R. P. Frankcl, L. M. Jack, M. W. Miller, and H. A. Schaefer, students in the University of Pennsylvania Law School.

${ }^{1}$ This estimate is based upon discussion with the Administrative Office of the United States Courts and several judges, district attorneys, and clerks. Available statistics comparc only the numbers of civil and criminal cases, c.g., in $194 \mathrm{r}$, a fairly typical year between prohibition and price control, 29,090 criminal cases and 28,909 civil cases were instituted in the eighty-four district courts. AvNual. Repont of the Director of the Administrative Office of the United States Courts (1947), Tables 3 and ro, pp. 92 and 113 . For comparison of civil and criminal case activity in recent years, see Charts 1 and 5 of the same REPORT, following pp. 29 and 35 .

The range of federal criminal enforcement is indicated in the classification, by offense, of the $3 \mathrm{I}, \mathrm{II}_{4}$ cases instituted in 1947 . The most active categories were:
Fraud and other theft $\ldots \ldots \ldots \ldots \ldots \ldots \ldots \ldots \ldots, \ldots \ldots \ldots$

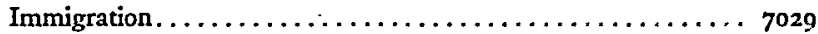
National Motor Vehicle Theft Act............... 3244

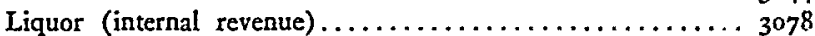

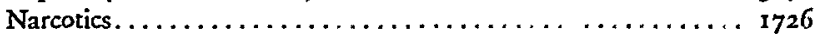

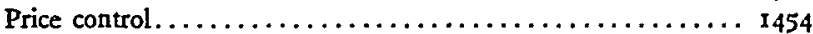

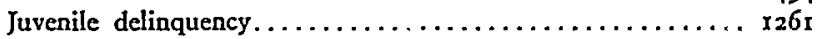
Selective service........................... I 86
Migratory bird offenses.................... 62 I

Other high-frequency categories included Motor Carrier Act violations, interstate transportation of women for immoral purposes, stowaway offenses, impersonation of federal officials, labor standards offenses, robbery and firearms offenses. Id., Table D-2.

The A. L. I. study of The Business of THE Federal Courts (1934) shows a gradual increase in criminal cases from about 5,000 in 1875 to about 15,000 a year from 1898 to 1917 , after which the curve moves upwards once more to the prohibition peak of over 90,000 in 1932. See Chart, p. 3I, and Table, p. ro\%.

Articles of Confederation (1777) Art. IX, U. S. Code (1940) p. xxv.

${ }^{3}$ Art. I, \$8, Art. III, \$3.

U. S. v. Worrall, 2 Dall. 384,28 Fed. Cas. 774 , No. 16,766 (C. C. Pa. 1798); U. S. v. Hudson, 7 Cranch 32 (U. S. I812); U. S. v. Coolidge, I Wheat. 415 (U. S. 1816). 
even the creation of federal courts, punished revenue frauds. ${ }^{5}$ Direct interferences with federal justice (e.g., perjury in a federal court, bribery of a federal judge) were dealt with in the Act of April 30, I790, "for the Punishment of Certain Crimes against the United States."6 By 1825, federal law extended to arson of a federal vessel (but only if "out of the jurisdiction of any particular State"), extortion by a federal officer, and theft by an employee from the Bank of the United States. ${ }^{\text {? }}$ Not until after the Civil War did the federal criminal law make its first substantial ventures beyond the punishment of acts directly injurious to the central government.

With two pieces of reconstruction legislation, the nation was launched upon the course of employing federal sanctions to protect private individuals from invasion of their rights by other private individuals-a traditional function of state law. In the Civil Rights legislation ${ }^{8}$ individuals were protected, under certain circumstances creating federal jurisdiction, against assault, murder, and threats. The Post Office Code of 1872 afforded the protection of federal criminal law against moral corruption and financial depredation, upon a showing that postal facilities had been used to promote fraud or lotteries, or to disseminate obscenity. ${ }^{9}$ It was during this period also that Congress provided for the removal to the federal courts of state proceedings, civil or criminal, "against any person who is denied or cannot enforce in the judicial tribunals of the State" his equal civil rights as a citizen of the United States, ${ }^{10}$ as previously it had provided for removal of state prosecutions for acts done in the capacity of a federal revenue officer. ${ }^{11}$ The states had shown an inability or unwillingness to protect the interests committed to their protection by the Constitution; now constitutional means had been forged or found to permit a more powerful protector to act. Nothing new in principle is added when it becomes criminal in IgIo to transport a woman in interstate or foreign commerce for immoral purposes, ${ }^{12}$ and in IgIg to transport a stolen motor vehicle in interstate commerce. ${ }^{\mathbf{1 3}}$ National prohibition perhaps marks the zenith of this movement; but even as it was laid to rest Congress pushed on with new penal laws in the 1930's directed at kidnaping, extortion, use of firearms, and many forms of theft, ${ }^{14}$ creating when necessary extraordinary presumptions to support federal jurisdiction, e.g., that the victim of a kidnaping has been transported in interstate commerce if he has not been released within seven days, ${ }^{15}$ and that a firearm was received in interstate commerce after

I STAT. 29, 46 (I789).

- I STAт. II2 (I790). This act also contained a general penal code for federal territories, within which Congress exercises a complete sovereign rather than a limited federal legislative jurisdiction.

${ }^{7} 4$ STAT. I15, II7-118 (1825).

${ }^{8}{ }_{14}$ STAT. 27 (1866); I6 STAT. I40, I44 (1870); see I8 U. S. C. $\$ \$ 5 \mathrm{I}$ and 52 (1940).

${ }^{9}$ I7 Stat. 283, 302, 323; see 18 U. S. C. $\$ \$ 334,336,338$ (1940).

${ }^{20} 12$ Stat. 756 (1863); see 28 U. S. C. $\$ 74$ (I940).

${ }^{11}{ }_{4}$ STAT. 633 (1833); see 28 U. S. C. $\$ 76$ (1940).

${ }^{12} 36$ StAT. 825 (I910), 18 U. S. C. $\$ 398$ (1940).

${ }^{23}$ 4I STAT. 324 (I9I9), I8 U. S. C. $\$ 408$ (I940).

"See symposium on the criminal legislation of the Seventy-third Congress, I Law \& Contemp.

Prob. 399 et seq. (1934); Conboy, Federal Criminal Law, in Law: A Century of Procress 295 (r937). ${ }^{15}{ }_{48}$ STAT. $78 \mathrm{I}$ (1934), 18 U. S. C. $\$ 408 \mathrm{a}$ (1940). 
the effective date of the Federal Firearms Act, if found in the possession of a defendant, previously convicted of a crime of violence. ${ }^{16}$

The gradual assumption of the power to punish for ordinary crimes proceeded concurrently with a great expansion of the role of the central government in many public-welfare fields. Interstate transportation, communication, and power distribution, the wholesomeness and proper labeling of food, the marketing of grain and securities, wages and hours of labor, the hunting of migratory game, and in wartime the price and distribution of nearly all commodities, were subjected to federal regulation. Nearly always the requirements of these regulatory measures were backed by criminal sanctions.

Thus federal criminal jurisdiction is being employed in three different ways: (x) to punish anti-social conduct of distinctively, if not exclusively, federal concern; (2) to punish conduct of local concern, with which local enforcement authorities are unable or unwilling to cope; and (3) to secure compliance with federal administrative regulations. ${ }^{17}$ It will be apparent in the ensuing discussion that these categories are not mutually exclusive; the most that can be said is that a particular federal criminal statute falls largely or primarily under one rather than another of these headings. It is the thesis of this article that federal criminal jurisdiction is an institution well adapted to the first use mentioned above, that it has been employed indiscriminately in the second category, and that a new federal court of inferior jurisdiction is needed to handle the considerable volume of petty offenses in category three. It will be urged that the proper employment of the federal court in the criminal field requires the recognition and practice of a much broader discretion by United States attorneys to turn over to state authorities persons who, by the same conduct, violate local laws as well as national laws intended to be auxiliary to local enforcement.

\section{I}

\section{Federal "Self-Deffenstve" Cruminal Jurisdiction}

There would be small profit in debating at this point in our history the question, "Shall we abolish federal criminal jurisdiction?" The institution's permanence is assured not only by the inertia of long tradition, but also by notable recent successes against traitors, kidnapers, racketeers, communists,' and others against whom public indignation is easily aroused. We may, however, explore with profit the extent to which federal prosecutors should invoke federal criminal jurisdiction, for, with the present arsenal of federal criminal statutes, the discretion of the Department of Justice is replacing the command of Cóngress in determining the working line between federal and state enforcement activities. The United States district

${ }^{10}{ }_{52}$ STAT. 1250 (1938), 15 U. S. C. $\$ 902(f)$ (1940). This prcsumption was invalidated in Tot v. United States, 319 U. S. 463 (1943).

${ }^{17}$ Cf. a somewhat similar classification in Arthur C. Milispavgh, Crume Control hy the Nattonal. GOVERNMENT 291 (Brookings Inst., 1937). 
attorney can generally find some federal hold on a situation. What are the considerations which lead him to act or to withhold his hand?

Given the federal criminal court, the strongest case for the exercise of its power can be made in the category of offenses which undermine the court itself or the governmental authority which the court represents. Thus few would question the propriety of federal punishment of treason, espionage, contempt of court, bribery of federal officials, resistance or obstruction to federal process, interference with recruiting, or defrauding the revenue. This is the oldest and best established branch of federal criminal jurisdiction. Important values in terms of prestige of the central authority are involved. The pomp and power of a court are potent symbols behind which to rally the allegiance of masses of people who might otherwise have difficulty envisioning a more remote and intangible sovereign. ". . . to surround the Constitution with more ramparts and to disconcert the schemes of its enemies," wrote Hamilton, urging extension of the federal judiciary, "the proper measures to be adopted [are] . . . First, establishments which will extend the influence and promote the popularity of the government. . .."1s A powerful federal court would bring federal authority and law "closer to the feelings, understanding and affection of all citizens." The extent to which the prestige of the federal system continues to rest upon the institution of the federal court in this day may be doubted. The armed forces, the income-tax collector, the post office, social security, and federal highways bring home to Everyman the strength and permanence of the central government. Perhaps present-day federal courts derive their prestige from the government rather than create it for the parent organization. But whether as an attribute of the court or of the government, this symbolic value of a federal criminal tribunal is clearly at its maximum in what might be called the self-defensive prosecutions by the federal government.

Moreover, in relation to such prosecutions there are valid administrative considerations which favor a separate federal tribunal. If genuinely national interests are at stake, the controversies should not have to compete with local breaches of the peace crowding the calendar of a county court of quarter sessions. The judge who determines these controversies should be able to give them the time and consideration appropriate to matters of such gravity. He should be a specialist in devising solutions that grow out of an understanding of national objectives and a national point of view. The exigencies of the Department of Justice are also to be considered. It is easier to prepare cases for eighty-four district courts, now operating under uniform rules of criminal procedure, than to conduct proceedings in thousands of courts operating under scores of procedural codes.

The possibility of conflict between local and national interests must also be

18 so Hamrion (Lodge ed.) 329, quoted in Warren, Federal Criminal Latvs and the State Cotrts, 38 HARv. L. REv. 545,558, n. 36 (1925).

${ }^{10}$ Warren, supra note 18 , at $56 \mathrm{x}$, quoting the Washington Federalist in the debate over the Judiciary Act of 1801 . 
envisioned, and provision must be made for resolving such conflicts by representatives of national authority if national law is to remain paramount. Possible local nullification of federal law was one of the Federalists' arguments for a strong national judiciary:

The most discerning could not foresee how far the prevalency of a local spirit might be found to disqualify the local tribunals for the jurisdiction of national causes; whilst every man may discover, that courts constituted like those of some of the States would be improper channels of the judicial authority of the Union. State Judges, holding their offices during pleasure, or from year to year, will be too little independent to be relied upon for an inflexible execution of the national laws. ${ }^{20}$

It is an argument which Congress has accepted as ground for broadening federal criminal jurisdiction at each of the recurrent states'-rights crises in our history. It may seem paradoxical that trial in a federal court should be effective to counter local resistance against federal law. Federal judge, jury, and prosecutor come from the same area and social groups from which the state court draws its personnel. Yet the very fact of employment by the central government seems to shift the center of loyalty and to modify or restrain local attitudes. There is a kind of esprit de corps uniting men to the organization to which, if only for the time being, they belong, that causes a juryman to react differently in the federal court than he would in his county courthouse across the street. ${ }^{21}$

Despite the considerations of national prestige, administrative convenience, and possible local obstruction, which justify reserving in the central government a power to act against anti-federal conduct, it does not follow that all conduct which adversely affects the federal organization must be dealt with in the federal courts. Early Congresses frequently relied on state courts to enforce penalties under federal revenue laws, and the doctrine that it is "inherently impossible" for the courts of one sovereign to enforce the penal laws of another as applied to the relations between Federal and state governments has been exploded by the removal cases. ${ }^{22}$ Theft of federal property is a federal offense, but it is also punishable by the states. ${ }^{23}$ Clearly federal prosecution would be in order against a conspiracy, perhaps with the con-

${ }^{20} 9$ Hamilton (Lodge ed.) 506, quoted in I E. N. Zoline, Federal Criminal Law \& Procedure (1921), Introd. p. $X$.

${ }^{21}$ See Mr. Justice Roberts' dissenting opinion in Screws v. United States, 325 U. S. 91, 158-159 (1945): "The Government further urges that, since prosecutions must be brought in the district where the crime was conmitted, the judge and jurors of that locality can be depended upon to protect against federal interference with State law enforcement. . . . If federal and State prosecutions are subject to the same influences, it is difficult to see what need there is for taking the prosecution out of the hands of the State. After all, Georgia citizens sitting as a federal grand jury indicted and other Georgia citizens sitting as a federal trial jury convicted Screws and his associates; and it was a Georgia judge who charged more strongly against them than this Court thinks he should have." Cf. evidence of the fairness of state court decisions on federal questions. Warren, supra note 18, at 569, 584 et seq.; Friendly, The Historic Basis of Diversity Jurisdiction, 4I Harv. L. Rev. 483, 492 et seq. (1928).

${ }^{22}$ Tennessee v. Davis, roo U. S. 257 (1879); see Warren, stupra note 18, at 576 et seq.

${ }^{23}$ State v. Stevens, 60 Mont. 390, 405, I99 Pac. 256 (x921); State v. Frach, 162 Ore. 602, 94 P. $2 d$ I 43 (1939). 
nivance of federal officials, to steal federally owned war surplus commodities held in warehouses throughout the country. Public confidence in the integrity of the distribution processes of the War Assets Administration is challenged. The Attorney General's purpose to vindicate federal authority would be hampered by any necessity to pursue the offenders through a number of local larceny prosecutions, and the deterrent effect would be considerably weakened. The federal property crimes, howver, reach far beyond such cases. Knowledge that the property belongs to the United States is not required, ${ }^{24}$ and one can imagine extreme applications of federal jurisdiction: a burglar ransacking the suburban home of a federal official takes a brief case belonging to the government; a pickpocket snatches a wallet containing OPA gasoline ration coupons. ${ }^{25}$ The dearth of such cases in the federal reports would indicate some common-sense self-restraint by federal prosecutors in invoking the sweeping power of federal theft legislation.

A situation intermediate between that of theft directed against the United States and theft which fortuitously involves United States property is presented by the stealing of mail matter. ${ }^{26}$ Here the principal victim is the owner of the article stolen, not the United States, although the Government has an interest as bailee sufficient to support an indictment for stealing federal property. ${ }^{27}$ The amount may be petty and the activity completely local. No regional obstruction of national policy is to be anticipated, and federal prestige is hardly staked on the conviction of a mail pilferer. Our standards may nevertheless imply the desirability of federal prosecution if small thefts are so numerous as to place a substantial operating burden on the postal system in tracing lost articles, or as to require expensive preventive measures. To protect the carrying out of this federal function may require coordinated enforcement efforts during which the cases should be singled out from other petty marauding for treatment in the tribunal of national concern. The penalty may be gauged by the special standard of reference to the needs of the federal system rather than by the value of the stolen property.

Another illustration of federal offenses which combine aspects of "self-defense" of the federal organization or function with the possibility of application to conduct containing very little of federal significance is impersonation of federal officials. ${ }^{28}$

24 The point seems rarely if ever to have been raised. See United States v. Kambeitz, 256 Fed. 247 , 255 (N. D. N. Y. I919), $a f^{7} d, 262$ Fed. 378 (C. C. A. 2d I919) (defendant stole furs and dresşes from a railroad express shipment while railroads were being operated by the United States); Thompson $\dot{v}$. United States, 256 Fed. 616 (C. C. A. 2d 1919) (defendant stole fifteen sacks of sugar from a river barge; United States ownership established by testimony of refiner's manager identifying this sugar from company records and code marks on the sacks as having been allocated to meet a requisition by the United States); Norris v. United States, 152 F. 2 d 808 (C. C. A. 5th 1946) (federal game warden rabbed of auto belonging to United States). Note in each of these eases the element of interference with some governmental function in addition to mere proprietorship.

${ }^{35}$ Under the regulations such coupons remained the property of the Office of Price Administration even after issuance. See Davis v. United States, 328 U. S. 582,588 (1946).

${ }^{30} 35$ STAT. Ir25 (I909), as amended, I8 U. S. C. $\$ 3$ I7 (1940).

27 United States v. Kambeitz, supra note 24.

${ }^{28}$ Sec. 32 of the Criminal Code, 52 STAT. 83 (1938), 18 U. S. C. $\$ 76$ (I940). 
A multiplication of cases of false assumption of federal authority may lead to a skepticism regarding credentials of genuine federal officers and may impede them in the exercise of their duties. Activities of impostors may also breed disrespect for federal authority. A power to prevent such consequences must be lodged in the federal authority, for reasons analogous to those applicable to postal depredation."0 The impersonation statute, however, is dratfed in terms as appropriate to private cheat as national menace. It permits a prosecution like Little v. United States, where the defendant, responding to a matrimonial advertisement by a widowed rooming-house keeper, bilked her of $\$ 30$ lodging, $\$ 7$ spending money, and a $\$ 600$ loan on the representation, among others, that he was a United States Secret Service operative.' A discreet prosecution policy in the light of the special function of the federal forum would have drawn the line well short of this case.

\section{II}

\section{Federal Criminal Jurssdiction Auxiliary to State Enforcemant}

There is even more reason for restraint in creating and exercising federal criminal jurisdiction auxiliary to state law enforcement. To enlist the federal power in the battle against obscenity, lotteries, theft, alcoholism, and prostitution is not to protect federal prestige but to hazard it; it does not solve federal administrative problems but creates new ones; it does not vindicate federal authority in matters of distinctively national concern against possible local obstruction, but steps into local issues. Federal intervention also has a tendency to weaken the enforcement efforts of state authorities. $^{31}$ If, nevertheless, national intervention is necessary, such intervention should proceed with an understanding of the disadvantages of dual state and federal criminal systems, disadvantages which are at their maximum when the federal law is employed to supplement local enforcement. The intervention, moreover, will be haphazard and arbitrary until there is full comprehension of the auxiliary role of the federal government; i.e., until we cease to regard the jurisdictional circumstance, which gives the United States power to act, as the "gist" of the federal offense.

\section{A. Anomalies of Dual Jurisdiction}

Were we not inured to the irrationalities which permeate our criminal law generally, the anomalies in its administration resulting from a dual judicial system would long ago have gained notoriety surpassing that of Swift $v$.Tyson. ${ }^{32}$ Substantially the same activities may be successively punished by both state and federal governments, ${ }^{33}$ although presumably the sentence imposed by each sovereign is

${ }^{29}$ See United States v. Lepowich, 318 U. S. 702 (1943).

${ }^{30} 169$ Fed. 620 (C. C. A. 9th 1909 ).

${ }^{31}$ See statement of Attorney General Mitchell, quoted in Hall, Federal Anti-Thefe Legislation, I LAw \& Contemp. Prob. 424, 432 (1934).

${ }^{32}$ I6 Pet. I (U. S. I842).

${ }^{33}$ Crossley v. California, 168 U. S. 640 (1898) (murder by derailing United States mail train); 
deemed by its legislature and courts appropriate to deter, reform, or incapacitate the offender. The dual jurisdiction has resulted in the so-called detainer system. A state prosecuting official, for example, will notify a federal warden that a prisoner is wanted for local prosecution after he has served his federal sentence. This prosecution may be for conduct which the federal judge took into account in imposing sentence, or even the identical conduct which was the subject of federal indictment. Parole authorities refuse to grant parole to prisoners against whom such detainers have been filed. Prisoner morale is undermined by knowledge of this practice and expectation of further imprisonment, with disastrous effect upon any program of reformation. Detainers are sometimes lodged with no real intention of prosecuting but solely to prevent parole. ${ }^{34}$

Only two significant limitations of the double punishment possibilities appear. One is a judicial doctrine restraining the states: they may not punish non-compliance with standards of conduct which conflict with those prescribed by Congress. ${ }^{35}$ The other is a legislative restraint on federal action: in connection with a few of the greatest extensions of federal jurisdiction over property offenses it has been provided that

A judgment of conviction or acquittal on the merits under the laws of any State shall be a bar to prosecution hereunder for the same act or acts. ${ }^{36}$

Absent such provision, acquittal in the courts of one system will not bar prosecution in the tribunals of the other system for the same transaction, ${ }^{37}$ although within each system immunity from double jeopardy ranks high among the traditional liberties of Anglo-American justice.

The dual court system and the extension of federal criminal jurisdiction in the "auxiliary" field harbor not only the possibilities of double trials and double punishment, but also problems of inequality of treatment of like offenders. Generally, duplicate prosecutions do not take place, although they are technically possible. A choice between federal and state action is made by the prosecuting authority. The

Hebert v. Louisiana, 272 U. S. 312 (1926) (illegal possession of alcoholic liquor). But cf. Puerto Rico v. Shell Co., 302 U. S. 253,264 et seq. (I937) (duplicate prosecution under territorial law barred since both laws emanate from same sovereign). Concurrent state jurisdiction is expressly provided for by Sec. 326 of the Criminal Code, 35 STAT. I15I (1909), I8 U. S. C. \$547 (1940), which is carried forward in Sec. 3231 of the proposed Revision of the Criminal Code, H. R. 3190, 80th Cong., Ist Sess. (1947): ". . nothing in this title shall be held to take away or impair the jurisdiction of the courts of the several states under the laws thereof."

${ }^{34}$ See criticism of this system by United States District Judge Carroll C. Hincks, Director of the Federal Bureau of Prisons James V. Bennett, and others in Federal Probation, reprinted in The New Era, Fall, r945, p. 20 et. seq.

${ }^{35}$ Easton v. Iowa, I 88 U. S. 220 (1903) (rev'g state conviction of national bank officer for receiving deposits after insolvency); State v. Thornton, 171 Minn. 466 (I927).

${ }^{30}$ Larceny of goods in interstate or foreign commerce, 37 .STAT. 670 (1913), as amended, 18 U. S. C. $\$ 4$ ro (1940). Train wrecking, 54 STAT. 255,18 U. S. C. $\$ 4$ I2a (I940). Theft and embezzlement by officcrs of interstate and foreign carriers, 38 STAT. 733 (I9r4), 18 U. S. C. $\$ 412$ (T940).

${ }^{37}$ United States v. Barnhart, 22 Fed. 285 (C. C. Ore. 1884) (acquittal in state court of a white man for murder of Indian no bar to prosecution in the federal court for killing the Indian on an. Indian reservation). 
choice will be significant to the defendant procedurally. For example, in the federal court he will have compulsory process to secure the attendance of witnesses from anywhere in the United States. ${ }^{38}$ The federal prosecutor, on the other hand, will find it easy to remove a defendant from place of arrest to place of trial under federal Criminal Rule $40_{3}^{39}$ as compared with the state prosecutor's necessity of resorting to interstate rendition. The defendant will find in the federal criminal courts an unusual solicitude to protect him against extra-judicial confessions secured by illegal methods of federal officials. ${ }^{40}$ But prosecution in the federal court will make available against him information, illegally obtained by state officers, which for that reason might not have been admissible against him in the state court. The privilege against self-incrimination and the right to be secure against unreasonable searches and seizures, protected within each system against encroachment by agents of that system, lose their efficacy when the invasion comes from one set of officials but is availed of by the other. ${ }^{41}$ The Supreme Court of Michigan in a very recent case seems to have been the first to recognize the mockery of this kind of privilege against selfincrimination in an era when criminal conduct is so likely to offend both federal and state law. ${ }^{42}$

More striking than the procedural variations is the effect of the choice of forum on the penalty which may be imposed. It may mean the difference between life and death, as under the federal kidnaping statute which authorizes the death penalty for an offense which in many states is not capital..$^{43}$ Fornication, if criminal at all, is rarely punished by the states. Let the defendant transport his mistress across the state boundary and he becomes subject to the five-year penalty of the Mann Act. ${ }^{14}$ Similar differences of treatment depending on the choice between federal and state prosecution occur in connection with federal legislation against the mailing of obscene or indecent matter or lottery advertisements. Indeed, these federal offenses may include some activities entirely lawful under state law, as where games of chance or dissemination of information on contraception has been legalized.

It will be objected against the foregoing analysis that procedural variations and inequalities of treatment are the natural consequence of the fact that the defendant's

${ }^{38}$ Fed. R. CRIM. P. 17, 18 U. S. C. A. (Supp. 1946), following 5687 .

so Ibid.

"McNabb v. United States, 318 U. S. 332 (1943).

${ }^{4 x}$ United States v. Murdock, 284 U. S. I4I, I49 (193I). (The opinion refers to the similar British rule which does not protect against compulsory disclosure of offenses violating laws "of another country.") Hałe v. Henkel, 201 U. S. 43 (1906); Jack v. Kansas, 199 U. S. 372 (1905).

${ }^{22}$ People v. Den Uyl, 29 N. W. 2d 284 (Mich. 1947).

${ }^{43}$ Cf. 50 STAT. 304 (1937), I8 U. S. C. $\$ 542$ (1940), authorizing the federal court to designate another state for execution "if the laws of the State within which the sentence is imposed make no provision for the infliction of the penalty of death. ..."

" 36 Star. 825 (1910), 18 U. S. C. $\$ 398$ (1940). Although this act was passed to enable the Federal Government to reach organized interstate prostitution, its application to isolated or essentially local offenses is possible and not infrequent. Caminetti v. United States, 238 U. S. 636 (1915); Unitcd States v. Reginelli, 133 F. 2d 595 (C. C. A. 3d 1943), cert. denied, 318 U. S. 783; cf. Cleveland v. United States, 329 U. S. I4 (I946); Mortensen v. United States, 322 U. S. 369 (1944). 
conduct gave rise to two separate causes of action, whereas the essential evil of the "federal common law" sponsored by Swift $v$. Tyson was that a plaintiff with a single cause of action was given power to choose a favorable forum. Neither the federal nor the state prosecutor has such a choice; each proceeds in his own tribunal for an offense committed against his own sovereign. This view has prevailed in the double-jeopardy cases previously discussed. A more realistic concept might be that federal and state prosecutors are, at least in the area of "auxiliary" federal criminal law, merely alternative instruments evolved by the American community for the purpose of deterring certain types of anti-social conduct or of reforming or incapacitating those who engage in such conduct. The community acts through its state organization where this is feasible, or, if the matter is beyond the effective control of that organization, through its national agencies and institutions. Treatment of the offender ought not to differ depending on the agency employed to administer the treatment. This is not to suggest that penalties under federal law be made to conform to those prescribed for cognate offenses under local codes. The point is only that the difference in treatment of similar conduct depending on whether state or federal government prosecutes is an additional reason for working out procedures. under which the states handle as many as possible of the offenses which do not involve a substantial federal interest. Where a true federal concern is involved, the significance of the defendant's transgression is changed, thereby justifying distinctions in penalty from local misconduct, as well as some national uniformity of treatment by the federal courts.

\section{B. Criteria for Limiting Employment of Federal Criminal Laws Auxiliary to State Enforcement}

Considering the vices of dual criminal jurisdiction, it is important to develop definite criteria for limiting the number of federal prosecutions under criminal laws which are merely auxiliary to state law enforcement. The Criminal Division of the Department of Justice must work these out in detail for each offense, but in general it can be said that federal action is justified in the presence of one or more of the following circumstances: ( $I$ ) When the states are unable or unwilling to act; (2) when the jurisdictional feature, e.g., use of the mails, is not merely incidental or accidental to the offense, but an important ingredient of its success; (3) when, although the particular jurisdictional feature is incidental, another substantial federal interest is protected by the assertion of federal power; (4) when the criminal operation extends into a number of states, transcending the local interests of any one; (5) when it would be inefficient administration to refer to state authorities a complicated case investigated and developed on the theory of federal prosecution. ${ }^{15}$ The following paragraphs illustrate the varying extent to which these considerations: seem to influence federal prosecution policy.

\footnotetext{
48 The analysis is drawn in part from a memorandum by Professor Herbert Wechsler of the Columbia University Law School.
} 
Frustration of state law enforcement by the territorial limitations on the authority of its officers is an obvious occasion for federal assistance. The Federal Fugitive Felon Act lays the basis for such assistance by making it unlawful to move across state lines to avoid prosecution by a state for certain relatively serious offenses, or to avoid testifying in state felony proceedings. ${ }^{* 6}$ This law was intended to provide a jurisdictional basis for FBI assistance in apprehending the fugitive (since the Bureau can investigate only federal crimes), and to facilitate removal (at federal expense) of the defendant to the jurisdiction from which he has fled. In view of this it has always been the policy of the Department of Justice to authorize complaints under this act only at the instance of state authorities and to release the defendant to state authorities after removal. Only rarely. would federal prosecution be appropriate under this "auxiliary" statute. Yet it has been invoked against a New Jersey doctor who in New Jersey removed identifying scars of a burglar fugitive from North Carolina, on the theory that the doctor was an accessory after the fact to the federal felony of interstate flight. ${ }^{47}$ And a fugitive witness, who might have been punishable by the state only for contempt, recently received a four-year sentence under circumstances suggesting that the penalty was related to a crime for which he had been given immunity in the state proceedings. ${ }^{48}$

The mail fraud statute is a more typical case of federal intervention based on several of the criteria mentioned at the head of this section. A promoter in a western mining state mulcts a nation-wide "sucker list" year after year by fraudulent representations as to the amount of "probable" ore in a mine or by cleverly conditional promises of dividends in the near future. His neighbors, more sophisticated in the mores of mining promotion than distant farmers and urbanites, are unlikely to be victimized, and inclined to be tolerant of "representations of opinion" or "promises" when asserted as a basis for criminal liability or extradition. The scattered victims, on the other hand, have little leverage with which to secure action from their home authorities. Individual losses may be small, the expense of extradition heavy, the burden of proof as to likelihood of dividents from a mine thousands of miles away beyond the capacity of the county prosecutor. Here federal prosecution would be appropriate not only because of state inability to deal with the situation, but because the abuse of the mail privilege is an inherent element of the scheme. Such frauds could hardly operate except through this federally supported means of communication. The central government, therefore, assumes a responsi-

\footnotetext{
${ }^{40} 48$ Stat. 782 (1934), as amended, 18 U. S. C. $\$ 408 \mathrm{e}$ (1940). See Toy and Shepherd, The Problem of Fugitive Felons and Witnesses, I Law \& Contras. ProB. 415 (1934).

${ }^{47}$ United States v. Brandenburg, 144 F. $2 d 656$ (C. C. A. 3d I944) (conviction reyersed on ground that "burglarly," as used in the Fugitive Felon Act, meant common-law burglarly only. This prosecution can be understood only in the lighe of Brandenburg's previous successful encounters with the law and his ultimate capitulation in a federal narcotics prosecution in which entrapment was the chief legal issue. United States v. Brandenburg, I62 F. 2d 980 (C. C. A. 3d 1947).

${ }^{48}$ Hemans v. United States, 163 F. $2 d 228$ (C. C. A. 6th 1947). Perhaps occasional prosecutions are necessary to preserye the fiction that it is indeed the "peace of the United States" that is involved. Cf. Pollock, King's Peace in the Middle Ages, I3 Harv. L. REv. I77 (1900).
} 
bility that the facilities which it furnishes shall not be abused and that fraud shall not be subsidized by cheap federal means of dissemination. It will be recalled in this connection that punishing the user of the mails evolved as a supplement to the postmaster's administrative duty and discretion not to carry noxious articles. To employ the mail fraud statute here is not only to supplement state action against fraud but to support and protect a federal function.

But the mail fraud statute may also be used where state action is frustrated only by the corruption of state officials, and where use of the mails is an unintended and remote incident of the scheme. Thus Leche $v$. United States ${ }^{40}$ and Hart $\nu$. United States ${ }^{30}$ were cases of ordinary local political graft in the sale of property to the State of Louisiana at exorbitant prices, with the connivance of the governor and other officials. Federal jurisdiction rested upon the fact that checks for the proceeds of the frauds were deposited in banks other than those upon which they were drawn. The banks of deposit forwarded the checks for collection from the drawee bank, by mail. The fraud was local in its execution and effect; the offenders were within reach of state process, and state law was adequate to the situation. But the defendants' dominance over the state government gave them immunity until the federal government intervened. Nevertheless, there was considerable resentment against this "interference with purely domestic affairs of the State," especially at the suggestion that the mail fraud statute might be used to police the Louisiana state primary election, on the theory that a dishonest election.would result in defrauding the state of the salary which it would pay to an improperly chosen official..$^{51}$

It is not surprising that hostility to federal intervention should be strongest when explosive race-relations issues are also involved; witness the savage congressional battles over the proposed anti-lynching legislation and the resistance to the application of the civil rights sections of the Criminal Code to punish official brutality against Negroes, where local prosecutors refuse to act. ${ }^{52}$ Screws v. United States was such a case. ${ }^{53}$ A Georgia county sheriff beat to death a Negro whom he pur-. ported to be arresting. The sheriff was convicted under Section 20 of the federal Criminal Code, which makes it a crime under color of state law willfully to deprive any inhabitant of rights, privileges, or immunities secured or protected by the federal Constitution and laws. Four members of the Supreme Court were satisfied that the Act covered the facts, but voted for reversal of the conviction because the trial

${ }^{49} 118$ F. $2 \mathrm{~d} 246$ (C. C. A. 5th I94I), cert. denied, $3{ }^{\text {th }}$ U. S. 6I7, rehearing denied, $3 I_{4}$ U. S. $7 \times 2$ (I94I).

${ }^{20} 112$ F. $2 d$ r 28 (C. C. A. 5th 1940), cert. denied, 31 II U. S. 684 .

${ }^{51}$ Cf. United States v. Aczel, 219 Fed. 917 (D. Ind. 1915), aff'd, 232 Fed. 652 (C. C. A. 7 th 1916). See 86 Cong. Rec. 720, 2557 (1940) (Senator Pepper): "I proclaim it as the privilege of a State in a democratic Government even to have bad government, if its people want it to be bad. . . " See also Johnston, They Sent a Letter, The Saturday Evening Post, June 22, 1940, p. 29, col. I, pointing out that Louisiana grafters, as a result of the Federal Government's imprisonment of Capone on income tax fraud, had reported their unlawful gains thinking thereby to exclude any possibility of federal action. ${ }^{2}$ The civil rights legislation also serves a purpose which may properly be regarded as "self-defensive," e.g., United States v. Classic, 313 U. S. 299 (protection of federal election processes).

${ }^{23} 325$ U. S. 9 I (1945). 
judge failed to charge that the defendant must have had the specific purpose to deprive the prisoner of his constitutional right to trial by court rather than by ordeal. ${ }^{54}$ Justices Rutledge and Murphy would have affirmed:

Too often unpopular minorities, such as Negroes, are unable to find effective refuge from the cruelties of bigoted and ruthless authority. States are undoubtedly capable of punishing their officers who commit such outrages. But where, as here, the states are unwilling for some reason to prosecute such crimes the federal government must step in unless constitutional guarantees are to become atrophied..$^{55}$

Mr. Justice Roberts, with Justices Frankfurter and Jackson, thought that:

The only issue is whether Georgia alone has the power and duty to punish, or whether this patently local crime can be made the basis of a federal prosecution. The practical question is whether the States should be relieved from the responsibility to bring their law offcers to book for homicide, by allowing prosecutions in the federal courts for a relatively minor offense carrying a short sentence.

They read the language and legislative history of Section 20 as conclusively against application to a state officer who "flouts State law and is unquestionably subject to punishment by the State for his disobedience."57

The arguments in the Screws case evoked one of the infrequent official disclosures of the role of prosecutor's discretion in the distribution of criminal business between federal and state courts. The brief of the United States sought to minimize the danger of federal displacement of state authority by demonstrating the Department of Justice's self-restraint:

The Department of Justice has established a policy of strict self-limitation with regard to prosecutions under the civil rights acts. When violations of such statutes are reported, the Department requires that efforts be made to encourage state officials to take appropriate action under state law. To assure consistent observance of this policy in the enforcement of the civil rights statutes, all United States Attorneys have been instructed to submit cases to the Department for approval before prosecutions or investigations are instituted. The number of prosecutions which have been brought under the civil rights statutes is small. . . Since 1939, the number of complaints received annually by the Civil Rights section has ranged from 8,000 to $x_{4}, 000$, but in no year have prosecutions under both Sections 20 and 19 , its companion statute, exceeded $76 . \ldots$

Complaints of violations are often submitted to the Department by local law enforcement officials who for one reason or another may feel themselves powerless to take action under state law. It is primarily in this area, namely, where the official position of the wrong doers has apparently rendered the State unable or unwilling to institute proceedings, that the statute has come into operation. ${ }^{58}$

${ }^{61}$ Id. at 107 .

${ }^{65} \mathrm{Id}$. at 138 .

${ }^{50}$ Id. at 139. Cf. Crews v. United States, I60 F. $2 d 746,747$ (C. C. A. 5th 1947), affirming conviction on a similar set of facts: "The defendant, although guilty of a cruel and inexcusable homicide, was indicted and convicted merely of having deprived his helpless victim of a constitutional right, under strained construetions of an inadequate Federal statute, and given the maximum sentence under that statute of one year in prison and a fine of $\$ 1,000 . "$

"T Screws v. United States, 325 U. S. 91, 142 (1945).

${ }^{\mathrm{E}} \mathrm{Id}$. at $159-160$. 
To this Mr. Justice Roberts replied:

If it be significantly true that crimes against local law cannot be locally prosecuted, it is an ominous sign indeed. In any event, the cure is a reinvigoration of State responsibility. It is not an undue incursion of remote federal authority into local duties with consequent debilitation of local responsibility. ...

Regard for this wisdom in federal-State relations was not left by Congress to executive discretion. ${ }^{59}$

The role of discretion in the distribution of law enforcement responsibilify between state and federal governments is therefore emerging as an important judicial as well as political issue. The Screws case serves notice upon Congress and the Attorney General to develop, perfect, and properly circumscribe this essential discretion. Congress must make it plain beyond question that it does rely upon the Attorney General's self-restraint, when it passes criminal laws that supplement state efforts. The Attorney General can do much to allay the suspicion which inevitably clouds areas of large executive discretion, by articulating in a public and formal fashion the criteria which guide him in exercising this discretion, not only in civil rights cases but in all offenses against auxiliary federal criminal laws. A beginning, but only a beginning, has been made in the standing Instructions to United States Attorneys, which circulate only within the Department.

\section{Inadequate Statutory Formulation of Federal Auxiliary Criminal Jurisdiction}

Up to this point emphasis has been placed upon the fact that definition of federal crime in terms of the circumstance which confers federal jurisdiction often brings into the national courts matters which might be left to the states. It is also true, however, that Congress has not fully exploited its constitutional powers to deal with crime, either to protect federal interests or to supplement state forces. Preoccupied with the jurisdictional problem, it has legislated against "use of the mails," or "transportation in interstate commerce," rather than against fraud or theft wherever they occur within reach of the federal power. This results in some surprising lacunae in the federal hold on crime. The central government will move against fraudulent schemes if the defendant "for the purpose of executing such scheme" uses the mails in minutely specified particular ways. ${ }^{60}$ But if the culprit eschews the mails and carries out his scheme by interstate telephone, he is exclusively in the hands of state authorities, unless perchance the scheme involves securities ${ }^{61}$ or use of a

${ }^{20} I d$. at $160-16 \mathrm{r}$. Cf. Mr. Justice Rutledge's opinion at page 132. The recent filing of a petition with the United Nations by the National Association for the Advancement of Colored People complaining of anti-Negro discrimination in this country and the report of the President's Committee on Civil Liberties presage a more active role for the Federal Government in this field. Attorney General Tom C. Clark is quoted in an Associated Press dispatch of October 27, 1947, addressing the National Association of Attorneys General, as follows: ". . . in those instances where the States through negligence, or for whatever reason, fail in their obligation to protect the life and liberties of the individual citizen, we shall move with as great vigor and force as is permitted under the law." The Washington Post, Oct. 28, 1947, p. 7 , col. 5 .

${ }^{80} \mathrm{Sec} .215$ of the Criminal Code, 35 STAT. II30 (1909), I8 U. S. C. $\$ 338$ (1940).

${ }^{61}$ Sec. I7(a) of the Securities Act of 1933, 48 STAT. 84 , 15 U. S. C. \$77q(a) (1940). 
"facility of a national securities exchange." finds expression in Section 213 of the Criminal Code, punishing not the use of the mails in furtherance of lottery schemes, as in the mail fraud statute, but only the mailing of specific kinds of lottery material and advertisements. ${ }^{.3}$ This is supplemented by Section $2 \mathrm{r}_{4}$, which makes the actor's status as a postal employee the basis of a general prohibition against his engaging in the sale of lottery tickets. Radio broadcasting of lottery information is a federal misdemeanor. ${ }^{64}$ Importation or interstate transportation of the same material is a felony. ${ }^{65}$ But it is apparently lawful from a national standpoint to transmit lottery information by interstate telephone or telegraph. Sellers of revolvers, forbidden to mail these weapons, mark their sales catalogues, "Must be shipped by express."

Stealing is a federal offense if the property belongs to or is in custody of the federal government ${ }^{07}$ or of a Federal Reserve, national, or federally insured bank. ${ }^{08}$ Stealing is also a federal offense if the property moves as or is part of an interstate or foreign shipment, or if the property is in the possession of an interstate carrier, or of a person moving in interstate or foreign commerce by carrier, or if the property is money "arising out of or accruing from" interstate or foreign transportation and is converted by an employee of the carrier. ${ }^{99}$ In contrast to the foregoing requirement of possession by an interstate carrier or movement as an interstate shipment, actual interstate transportation of the stolen articles is required under the National Motor Vehicle Theft Act ${ }^{70}$ and under the National Stolen Property Act. ${ }^{71}$ Under the Antiracketeering Act the Federal Government may become the prosecutor of robbery or extortion which in any way or degree obstructs, delays or affects interstate or foreign commerce. ${ }^{22}$

Kidnaping becomes of potential. federal concern as a result of the interstate or foreign transportation of the victim, the statute being obviously patterned upon the National Motor Vehicle Theft Act, to which the editors of the United States Code append it. ${ }^{73}$ Jurisdiction might as easily have been rested on the use of the mails or means of interstate commerce in connection with the kidnaping, since ransom notes and telephone calls are a usual feature of such operations. This hiatus is

"Secs. Io and 32 of the Securities Exchange Act of 1934, 48 Srar. $89 x$, 904 15 U. S. C. $\$ 578$, $78 \mathrm{ff}$ (a) (1940).

35 STAT. Ir29 (1909), I8 U. S. C. $\$ 336$ (1940).

os Federal Communications Act of June 19, I934, 48 STAT. 1088, 47 U. S. C. $\$ 316$ (1940).

${ }^{\text {aE Sec. }} 237$ of the Criminal Code, 35 STAT. I136 (1909), I8 U. S. C. $\$ 387$ (1940).

${ }^{\text {oo }} 44$ STat 1059 (1927), as amended, 18 U. S. C. $\$ 36 \mathrm{r}$ (1940). Sec Brabner-Sinith, Firearm Regalation, I LAw \& ConteMp. ProB. 400, 405 (1934).

${ }^{67}$ Secs. 46 and 47 of the Criminal Code, 35 STAT. 1097 (1909), 18 U. S. C. $\$ \$ 99$ and 100 (1940). See provisions as to stealing from the mails, Secs. 192 and 197 of the Criminal Code, 18 U. S. C. $\$ \$ 315-$ 320 (1940). (1940).

${ }_{48}^{88}$ STAT. 783 (1934), 12 U. S. C. $\$ 588$ a (1940); REv. STAT. $\$ 5009$, as amended, r 8 U. S. C. 5592

${ }^{19} 37$ STAT. 670 (rgr3), as amended, 18 U. S. C. $\$ 409$ (a) (I040).

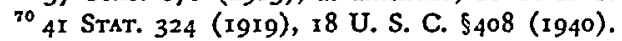

${ }^{71} 48$ STAT. 794 (1934), I8 U. S. C. $\$ \$ 413-419$ (1940).

$72{ }_{4} 8$ STAT. 979 (I934), as amended, 18 U. S. C. $\$ 420 a$ (I940).

${ }^{73} 47$ Stat. 326 (1932), as amended, I8 U. S. C. $\$ 408$ a (1940). 
partially filled by the statutory provisions relating to extortion and demand for ransom. These fall within the federal ken if the communication is transmitted in interstate commerce or through the mails but, for reasons difficult to fathom, the communication itself must contain the threat or demand before the Federal Bureau of Investigation or the postal inspectors can be called in. This is the more surprising since it was long ago held that letters on which a mail fraud count may be based need not contain the fraudulent misrepresentation, if in fact the letter promotes the fraudulent scheme. ${ }^{74}$ In the case of mail fraud, letters are sufficient which merely lull the victim into a false sense of security after he has parted with his money. ${ }^{75}$

The foregoing list illustrates congressional employment of the following jurisdictional bases for adding federal to state sanctions against undesirable conduct: ( 1 ) use of the mails; (2) use of means of interstate commerce; (3) "affecting" commerce; (4) interstate transportation (a) of the victim, (b) of the proceeds, (c) of the criminal himself; (4) radio broadcasting; (5) status of the offender as a federal employee; (6) status of the offender as an employee of an interstate carrier; (7) use of facilities of national securities exchanges; (8) federal ownership or custody of the property; (9) ownership or custody of the property by institutions licensed by the federal government or under its protection. The list can, of course, be extended almost indefinitely with crimes resting on the tax, war, and other powers of Congress. Enough has been said, however, to show that the use of a particular jurisdictional circumstance in the definition of a federal crime only very crudely marks off the area in which either ( $x$ ) a substantial national interest exists or (2) the states are incapable of effective action. The legislation reaches too far in many situations but may fall short in a particular case despite an obvious federal interest. Attention and controversy tend to focus on the jurisdictional problem rather than the substantive issues of criminality. Federal jurisdiction may turn on the distinction between transporting "with fraudulent intent" and mailing "for the purpose of executing a scheme to defraud."76 Courts find themselves talking nonsense like the oft-repeated declaration that the use of the mails is the "gist" of the offense of mail fraud, when all that is meant is that this federal jurisdictional element must, of course, be alleged and proved. ${ }^{77}$ To regard mailing as the essence of mail fraud is like treating the localization of the offense in Pennsylvania as the gist of a Pennsylvania prosecution for larceny. One example of the peculiar and artificial results of this attitude toward federal crime is the doctrine that each use of the mails in connection with a single

\footnotetext{
${ }^{24}$ Durland v. United States, I6I U. S. 306 (1896); United Stares v. Berg, I44 F. 2d 173 (C. C. A. 3d 1944).

${ }^{75}$ MeNear v. United States, 6o F. 2d 86I (C. C. A. 8th 1932); United States v. Spielberger, 28 F. Supp. 380 (W. D. Va. 1939); but cf. Merrill v. United States, 95 F. 2 d 669 (C. C. A. 9th 1938).

${ }^{70}$ Compare Kann v. United States, 323 U. S. 88 (1944) with United States v. Sheridan, 329 U. S. $379(1946)$.

${ }_{77}$ United States v. Crummer, I5I F. 2d 958, 962 (C. C. A. Ioth 1945), cert. denied, 66. Sup. Ct. 704 (holding scheme need not be alleged with same particularity as is required in pleading the mailing); United States v. Lowe, II5 F. 2d 596, 598 (C. C. A. 7th I94I), cert. denied, 3II U. S. 7I7; United States v. Quimby, 5I F. 2d 167 , 170 (C. C. A. 2d 193I).
} 
scheme constitutes a separate offense, so that the limit of the federal court's power to punish for fraud is five years multiplied by the number of different letters which the prosecutor cares to make the subject of separate counts in the indictment. ${ }^{78}$ For a single use of the mails in connection with a nationwide fraud a defendant chances no more than five years in a federal penitentiary. Five post cards to a single victim in connection with the sale of an automobile by false representations gives the federal judge discretion to impose twenty-five years. An acquittal in one mail fraud trial will not bar a subsequent trial and conviction for the same fraud based on another letter. A count setting forth more than one mailing would be duplicitous.

Against such a background it is not surprising that a foreign court should be misled regarding the nature of our federal penal law, to an utterly impractical result. In Re Lamar, ${ }^{\text {;9 }}$ the Supreme Court of Alberta refused an American request for extradition of Lamar for mail fraud, on the ground among others that the offense was not within the extradition treaty. The treaty did cover fraud and false pretense, and a request by the governor of a state for Lamar's extradition would have been honored. But since the national government wanted him for an offense the gist of which was mailing, the court could find no basis for giving him up, under the general principle of international extradition law that the offense must be punishable in the asylum state. Mail fraud (like other federal offenses defined by reference to particular jurisdictional features) is a unique American penological phenomenon.

Rationalization of the federal penal code would call for definitions of federal crimes in terms of the significant criminal conduct. The jurisdictional features necessary to give federal authorities power to act should be brought together in a comprehensive definition of some phrase like "within the federal jurisdiction." Such a wholesale enlargement of federal power will, of course, be unacceptable to Congress without an assurance of proper restraint in the exercise of the jurisdiction. Perhaps the first evidences of a changing attitude toward federal crime can be discerned in the pending Revision of the Criminal Code. ${ }^{80}$ The Revision abandons the present organization of federal criminal law under captions referring to jurisdictional elements like "offenses against postal service," "offenses against foreign and interstate commerce," "offenses within admiralty, maritime and territorial jurisdiction of United States." Instead there is to be an alphabetical arrangement of offenses by nature of the conduct prohibited, e.g., arson, assault, embezzlement and theft, false personation, lotteries, obscenity. Chapter $3 \mathrm{r}$ of the Revision, entitled Embezzlement and Theft, will bring together the various provisions of federal law dealing with these property offenses, heretofore scattered through the code under appropriate jurisdictional headings. It was found possible to consolidate eleven different sections

${ }^{78}$ Mitchell v. United States, I42 F. $2 \mathrm{~d}{ }_{4} 80$ (C. C. A. Ioth 1944), cert. denied, 323 U. S. 747; Bozel v. United States, 139 F. 2d 153 (C. C. A. 6th 1943), cert. denied, 321 U. S. 800; Holmes v. United States, 134 F. 2d 125 (C. C. A. 8th 1943), cert. denied, 319 U. S. 776. The practice has been disap. proved. United States v. Steinberg, 62 F. $2 d$ 77, 78 (C. C. A. 2d 1932), cert. denied, 289 U. S. 729 (but court held without power to interfere).

${ }^{79} 2$ Western Weekly Report 47I, 477 (Supreme Court of Alberta 1940).

${ }^{80}$ H. R. 3190,80 th Cong., Ist Sess. (1947). 
into one. ${ }^{81}$ The juxtaposition of the remaining sections revealed the need for uniformity of definition and penalties. ${ }^{82}$ Robbery and burglary offenses-within federal territorial jurisdiction, of federal property, from federally protected banks, in a post office, or in a railroad car carrying interstate shipments-are assembled in Chapter 103. However, within the chapters the individual identity of the offenses is largely preserved, e.g., transportation, mailing, and broadcasting of lottery matter remain distinct offenses and existing penalty variations depending on which jurisdictional element is invoked are retained. It will still be no federal offense to use the interstate telephone and telegraph for lottery purposes.

\section{III}

\section{Petty Offenses and the United States Commussioner}

Few are aware of the extent to which the federal courts are occupied with petty offenses that would be handled by magistrates or police courts in the state systems. Petty offenses are defined in the federal Criminal Code as those for which the penalty does not exceed confinement in a common jail, without hard labor, for a period of six months, or a fine of not more than $\$ 500$, or both. ${ }^{83}$ Such offenses may be prosecuted on complaint, and tried summarily without a jury if Congress so provides, at least where the offense is "malum prohibitum." Among the federal offenses which fall within this category are: violations of the statutes regulating hunting and conservation of migratory game, ${ }^{85}$ unauthorized manufacture, sale, on possession of federal official insignia, unauthorized wearing of uniform of the armed services or of a federally incorporated veterans organization, fraudulent use of the emblems of the Red Cross or of the $4-\mathrm{H}$ Clubs, ${ }^{86}$ enticing workers away from a federal armory ${ }^{87}$ petty cheating of the post office and violation of postal regulations. ${ }^{88}$ Federal judges and prosecutors are often reluctant to employ the federal district courts for such cases. It has seemed to them inconsistent with the dignity of the national tribunal to thrust upon it the duties of a justice of the peace, as in the case of violation of the game laws, or to invoke the mighty force of the Union to assess small fines. ${ }^{89}$ This

${ }^{01}$ H. REP. No. 304 on H. R. 3190, 80th Cong., rst Sess. (1947).

8 Reviser's notes on $\$ \$ 641,645,659$ in H. REP. No. 304 on H. R. 3190,80 th Cong., rst Sess. (1947).

${ }^{83} 46$ STAT. 1029 (1930), I8 U. S. C. $\$ 54$ I (1940).

8s Schick v. United States, r95 U. S. 65 (rg04) (proceeding for statutory penalty for violating Oleomargarine Act; jury trial waived); but of. District of Columbia v. Colts, 282 U. S. 63 (r930) (holding reckless driving malum in se, requiring jury trial). See Frankfurter and Corcoran, Petty Federal Offenses and the Constitutional Guaranty of Trial by Jury, 39 HARv. L. Rev. 917, 975 et seq. (I926).

${ }^{85} 40$ Stat. 755 (I918), as amended, I6 U. S. C. $\$ 703$ (1940); 45 Stat. r222 (1929), I6 U. S. C. 5715 (I940); 48 STAT. 452 (1934), 16 U. S. C. \$718 (1940).

oe These provisions are conveniently assembled in Chapter 33 of the pending Revision of the Criminal Code, H. R. 3190, 8oth Cong., Ist Sess. (1947). See H. REP. No. 304 for cross references to existing sections.

${ }^{87}$ Sec. 43 of the Criminal Code, I8 U. S. C. $\$ 95$ (1940).

"See Chapter 83 of the pending Revision of the Criminal Code.

"See National Commission on Law Observance and Enforcement, Report No. 2 on the ENforcement of the Prohibition Laws of the United States (I931), H. R. Doc. No. 722, 7ist Cong., 3d Sess. 56 (1931). See also Report No. 8 on Criminal Procedure 7-8 (U. S. Government Printing Office 193r). 
becomes more serious when the attitude manifests itself against prosecution of minor violations of federal regulatory measures which do not technically fall within the definition of petty offenses, e.g., violations of the Fair Labor Standards Act, ${ }^{00}$ the Food, Drug and Cosmetic Act of $1938,{ }^{01}$ the stowaway laws, ${ }^{92}$ or the Emergency Price Control Act. ${ }^{93}$

Following a study of the petty offensel problem under prohibition, President Hoover endorsed legislation recommended by the National Commission on Law Observance and Enforcement, to define "casual or slight violations," which the district attorney might prosecute on complaint, limiting punishment as in the present definition of petty offenses. Such complaints would be heard by the United States Commissioner as an arm of the district court. The Commissioner would accept pleas, hold hearings, and report cases to the district judge for sentence. The accused might, if conviction were recommended, demand jury trial in the district court, but in that event he subjected himself to the normal penalties for violating the statute. ${ }^{04}$ Nothing came of these recommendations except the enactment of the petty offense definition previously mentioned. The principal function of the United States Commissioner under the present statutes is that of committing magistrate. ${ }^{95}$ In recent years the statutes creating various national parks have authorized the federal district courts to designate commissioners to try violations of the park regulations and other petty offenses committed in the parks. ${ }^{96}$ In r940 Congress took another short step in the direction of establishing federal police courts when it enacted that any United States Commissioner specially designated for that purpose by the court might, upon consent of the defendant, try petty offenses committed within the exclusive or concurrent federal jurisdiction. ${ }^{97}$ As in the case of the park commissioners, conviction by the Commissioner may be appealed to the district court.

It is to be expected and hoped that the Commissioner's power to deal with petty. offenses will be expanded along the lines indicated in the Wickersham Commission recommendations. Recent English development has gone much further, to the extent of making serious offenses triable summarily on consent of the defendant. ${ }^{.8}$ Nor is there occasion for shock at the proposal to entrust to the federal prosecutor

${ }^{90} 52$ STAT. 1069 (1938), 29 U. S. C. \$216 (1940), maximum penalty for second offender six months imprisonment or $\$ 10,000$ fine.

${ }^{01} 52$ STAT. 1043,21 U. S. C. $\$ 333$ (a) (1940).

85 STAT. 306 (1940), as amended, 18 U. S. C. $\$ 469$ (1940).

${ }^{23} 56$ STAT. 33 (1942), as amended, 50 U. S. C. App. \$925 (Supp. 1946).

a Supplemiental Report on Observance and Enforcenent of Promibition (1929), in $H . R$. Doc. No. 252, 7Ist Cong., 2d Sess. 25 (I93I).

os Rev. Stat. \$1014 (I875), I8 U. S. C. \$59I (1940). See Griffin, United States Commissioners, 29 J. AM. Jud. Soc'Y 58 (1945); United States ن. Maresca, 266 Fed. 713 (S: D. N. Y. 1920).

${ }^{80} \mathrm{Sec}$, for example, 16 U. S. C. $\$ \$ 67,100,172,376$ (1940).

${ }^{97} 54$ STAT. 1058, 18 U. S. C. $\$ 576$ (1940).

98 The Criminal Justice Act (1925) \$24. See Penal Reform in England 56-58 (2d ed. 1946), edited by Radzinowiz and Turner for Department of Criminal Science, Faculty of Law, University of Cambridge. Included among the offenses triable summarily are forms of "larceny, malicious mischief, perjury, and indecent assault, carrying penalties as severe as life imprisonthent (e.g., larceny of postal packets, Sec. 12 of the Larceny Act, 1916). 
discretion to resort to a forum and procedure which limits the maximum penalty that may be imposed. In his determination whether to prosecute at all, whether to proceed in federal court or to remit the offense to state prosecutors, for what offenses to prosecute, how many substantive counts to include and whether to include a conspiracy count, the prosecutor makes decisions of much greater significance to the defendant, subject to no control whatsoever by the defendant and little by the court. Moreover, the existing discretion is exercised, as it were, in camera, for no one other than the district attorney and the defendant can judge the extent of its exercise, whereas the present proposal involves an overt exercise of discretion.

IV

\section{Prosecutor's Discretion}

The role which this essay assigns to the district attorney's discretion is a large one, and it is necessary to indicate the extent to which it is consistent with our institutions. This will be done by reviewing instances of judicial, legislative, and executive recognition of the discretion, first, in relation to the institution and maintenance of criminal cases generally and, second, with specific reference to the power to forego federal prosecution where state and national jurisdiction are concurrent.

The question of the district attorney's discretionary control of criminal prosecution has arisen most often in connection with the filing of a nolle prosequi, and the courts have regularly refused to interfere with these voluntary dismissals of prosecution. ${ }^{\text {09 }}$ Congress, well aware of this exercise of discretion, has never challenged its existence even when the wisdom of a particular decision was under attack. In the hearing on the confirmation of Attorney General Jackson as Associate Justice of the Supreme Court, the nomination was attacked because of Jackson's failure to prosecute Drew Pearson and Robert S. Allen for criminal libel on Senator Tydings. Jackson had taken the position that it was the policy of the Department of Justice to avoid the criminal libel laws when the courts were open to the injured party in civil proceedings, and that prosecutions of this character would tend to impair freedom of the press. Republican Senator (now Mr. Justice) Burton stated:

The prosecuting attorney, being charged, as he is charged, with the great responsibility of deciding under the laws of the United States, the laws under which he is serving, whether a case should be prosecuted, owes a duty to himself, his community, and the Constitution to decide whether the case should be prosecuted. ... In my judgment the Attorney General was within his rights when he declined to prosecnte, and in stating the grounds as he did state them under the circumstances. ${ }^{100}$

The Executive branch of the Federal Government has not doubted the existence

${ }^{10}$ United States v. Brokaw, 6o F. Supp. 100 (S. D. Ill. I945); United States v. Woody, 2 F. 2d 262 (D. Mont. 1924), ct. United States v. Bioff, 40 F. Supp. 497 (S. D. N. Y. 194I). A prosecutor cannot be mandamused to prosecute. Murphy v. Sumners, 54 Tex. Cr. 369, II2 S. W. ro7o (1908); Graham v. Gaither, I 40 Md. 330, I17 Atl. 858 (1922).

${ }^{100} 87$ Cong. REc. 5954, 5956 (1941). See also Hearings before the Subcommittee of the Senate Committec on the Judiciary on the Nomination of Robert $H$. Jackson, 77th Cong., Ist Sess. 55, 58, 5962,64 (ro41); cf. pp. 2, 13, 15 of the Hearings (dismissal of the Spanish loyalist recruiting indictments). 
of this broad discretion in relation to prosecutions. Executive Order No. 6166 of June I0, 1933, which, among other things, centralized the prosecuting function in the Department of Justice, described that function as "decision whether and in what manner to prosecute ... or to abandon prosecution." Attorney General Cummings' opinion accompanying this executive order reviews a line of previous opinions of Attorneys General in support of their right to pass on questions of "expediency and propriety" in conducting the government's legal business. ${ }^{101}$ The extent to which the Department of Justice does exercise discretion in instituting prosecution has already been noted. Administrative agencies which investigate and refer cases to the Department of Justice for prosecution have developed quite explicit standards for selecting cases for penal treatment. These standards naturally reflect those of the Justice officials who have to be persuaded to proceed with the cases. Thus the Enforcement Manual of the Office of Price Administration stated the "general considerations" bearing on the selection of cases for criminal prosecution as follows:

OPA cannot use the criminal remedy for wide coverage of offenders, as is done in England, because it would unduly flood the Federal Courts. Instead, OPA must develop techniques and criteria for choosing a relatively small number of key cases to prosecute criminally. OPA cannot in this way punish all violators who deserve criminal penalties. No prosecution should be recommended unless the case has clear significance for enforcement beyond the administering of deserved punishment. ${ }^{102}$

The Manual then reminded enforcement officers of alternative non-criminal sanctions-e.g., injunctions, penalty suits-to be weighed against criminal proceedings in the light of relative possibilities of success, speed of disposition, and other considerations. Prosecution was to be limited to intentional or wanton violations, a stricter standard than required by the statutory "willfulness." Among wanton and inten. tional violators, moreover, only "strategic," or "key" cases would be prosecuted. A case might be strategic because the violator was a leader in his industry or in a key position economically so that his price violations tended to cause similar violations by others. ${ }^{103}$ Except for flagrant cases, OPA would recommend prosecution only for the statutory misdemeanor under the Emergency Price Control Act or the Second War Powers Act, although there might be a factual basis for felony charges of conspiracy or making false statements in matters before a federal agency. ${ }^{104}$

In relation to the specific question of withholding federal prosecution in favor of state proceedings, reference may be made to the Screws opinion ${ }^{105}$ for the Department of Justice's conception of its responsibility vis-a-vis the states for protection of civil rights. Its policy under the Fugitive Felon Act, in favor of state action, has also been mentioned. It is the practice to dismiss federal charges against persons who have served or are serving adequate sentences in state institutions. ${ }^{108}$ In Mann

10138 Ops. ATT'y Gen: 98, I00 (r934-1937). $\quad{ }^{109}$ OPA Enforcement Manual, Sec. 9-1702.02.

${ }^{103}$ Id., Sec. 9-1702.04. ${ }_{104}$ Id., Sec. 9-1702.06. ${ }^{105} 325$ U. S. 91 (1945).

${ }^{100} \mathrm{Cf}$. Sec. 9-I702.05 of the OPA Enforcement Manual: "Criminal prosecution should not be recommended when a case against the same subject is pending in the state court for an infraction of state laws related to or connected with the transaction which also involves a violation of OPA regulations. ... 
Act prosecutions the district attorneys are to ask themselves, "What reasons if any exist for thinking the ends of justice will be better served by a prosecution under federal law than under the laws of the state having jurisdiction?"107 This echoes the opinion in United States $v . A h$ Hung, ${ }^{108}$ a prosecution for concealing opium with knowledge that it had been imported, in which the government relied upon the statutory presumption of knowledge of importation. In response to the defendant's argument that the matter was one for state action, the court said:

The federal jurisdiction is not exclusive. As in the case of the White Slave Act ... the existence of some real basis for the application of interstate commerce jurisdiction should be considered by those officers of the government on whom rests the responsibility for instituting prosecution.

His offense is of such a nature that it would be within the discretion of the United States Attorney to allow it be dealt with under the health and penal statutes of the state, regulating the welfare of the individual, rather than under interstate or foreign transportation of opium and its use as such. But [federal] jurisdiction over the case does exist. ${ }^{109}$

There is at least one instance of legislation expressly authorizing United States attorneys to forego federal prosecution. Following protest by Representative Dyer, author of the National Motor Vehicle Theft Act, against the commitment of hundreds of juveniles to federal institutions, ${ }^{110}$ Congress passed the Act of June in, 1932, ${ }^{111}$ declaring its preference for local handling of juvenile delinquency cases where jurisdiction is concurrent. The Act provides in part as follows:

For the purpose of cooperating with States ... in the care and treatment of juvenile offenders, whenever any person under twenty-one years of age shall have been arrested ... and, after investigation by the Department of Justice, it shall appear that such person has committed a criminal offense or is a delinquent under the laws of any State that can and will assume jurisdiction ... and that it will be to the best interest of the United States and of the juvenile offender to surrender the offender to the authorities of such State, the United States attorney of the district in which such person has been arrested is authorized to forego the prosecution of such person and surrender him as herein provided. ${ }^{112}$

The provisions in some of the federal theft legislation making conviction or acquittal in the state courts a bar to federal prosecution may also be regarded as an indication

In those cases where the subject may be prosecuted either under the state or federal laws, there should be close collaboration between state and federal authorities to determine the best forum for such prosecution." See also Sec. 9-I702.04(B): ". . There is little significance from the general enforcement point of view in prosecuting the petty criminal, especially where his conduct renders him amenable to state or federal law."

${ }_{107}$ Par. ${ }_{13} 8$ of Instructions to United States Attorneys, Dec. I, 1945. But see note 44, supra.

${ }^{108} 243$ Fed. 762 , (E. D. N. Y. 1917).

${ }^{109} \mathrm{Id}$. at 764,765 .

17072 Cong. Rec. 2494 (1930); see Hall, Federal Anti-Theft Legislation, I Lat \& Contexp. Proв. 424,428 (1934).

11147 STAT. 301, I8 U. S. C. \$662a (1940).

112 Ibid. 
of congressional sentiment in support of local responsibility. ${ }^{113}$ Of interest also in this connection is Section 323I of the pending Revision of the Criminal Code:

Offenses against the United States shall be cognizable in the district courts of the United States, but nothing in this title shall be held to take away or impair the jurisdiction of the courts of the several states under the laws thereof. ${ }^{114}$

This section would replace Sections 24 and $256(\mathrm{r})$ of the present Judicial Code, which expressly make federal court jurisdiction over federal crimes exclusive. ${ }^{115}$ Perhaps proposed Section $323 \mathrm{r}$ is intended to open the door to a suggestion made twenty-two years ago by Charles Warren, that state courts be employed for prosecution of federal offenses in order to reduce the work-load of the federal courts. ${ }^{110}$ But federal prosecutors will not prosecute for federal offenses in state courts, even if the state courts accept the jurisdiction. That has been the experience under the few federal criminal laws which expressly provide, contrary to Section $256(1)$ of the Judicial Code, that jurisdiction of the federal offense shall not be exclusively in the federal courts. ${ }^{117}$ If the purpose is to authorize discretionary relinquishment to local tribunals, for prosecution under state law, of offenses which are only technically but not substantially within the federal concern and jurisdiction, the matter could be handled much more directly by amending Section $77 \mathrm{r}$ of the Revised Statutes, which makes it the "duty" of every district attorney to prosecute "all" offenses cognizable under the authority of the United States. ${ }^{118}$ The language has, of course, not been regarded as precluding the exercise of discretion. However, if prosecutors' discretion is to be guided toward a rational coordination of federal and state criminal jurisdiction Congress should qualify this "duty to prosecute" with a generalization of the idea embodied in the Juvenile Delinquency Act. The language might be somewhat as follows:

Whenever any person is charged with any offense against the United States, and it shall appear to the satisfaction of the Department of Justice that such person has committed an offense under the laws of any state that can and will assume jurisdiction and deal with him according to the laws of such state, and that it will be to the best interests of the United States to surrender such person to the authorities of such state, the United States Attorney of the district in which such person has been arrested is authorized, subject to the regulations and instructions of the Attorney General, to forego prosecution for the federal offense and to surrender such person to the appropriate state authorities.

\section{$\mathrm{V}$}

\section{Concrusion}

This survey points to four lines of development by which federal criminal jurisdiction can become the instrument of an intelligent national penal policy: (r) The

${ }^{113}$ E.g., 37 STAT. 67O (19r3), as amended, I8 U. S. C. \$4ro (1940).

${ }^{114}$ H. R. 3190, 8oth Cong., Ist Sess. (1947). ${ }^{225} 28$ U. S. C. $\$ \$ 41$ and $371(1)$ (1940).

${ }^{116}$ Warren, Federal Criminal Laws and the State Courts, 38 Harv. L. Rev. 545, 597 (1925).

${ }^{112}$ Bank robbery, 48 STAT. 783 (1934), as amended, 18 U. S. C. $5588 \mathrm{~d}$ (1940).

${ }^{218} 28$ U. S. C. $\$ 485$ (1940). The language is scheduled to be carried over substantially unchanged in $\$ 507$ of the pending revision of the Judicial Code. H. R. 3214, 8oth Cong., Ist Sess. (1947). 
evolution of a broader, more uniform jurisdictional formula for federal criminal statutes; (2) the expansion of the power of the United States Commissioners to try petty offenses; (3) an express authorization by Congress of a general policy of remitting local offenders to local authorities; (4) articulation by the Department of Justice of a complete set of standards for the exercise of this discretion to withhold federal prosecution. With these, the use of national courts could be confined to matters of national import, and petty prosecutions could be segregated appropriately. The progressive weakening of local responsibility for local law enforcement could be halted, The new emphasis on federal-state relations might turn the Criminal Division of the Department of Justice towards a function which it has heretofore ignored: supplying leadership and technical counsel to state prosecuting agencies, helping local authorities to do their own job well rather than doing it for them. The Federal Bureau of Investigation of the Department of Justice has assumed this role within its field of policing and detection, by subsidizing, guiding, and educating local forces through its National Police Academy, Central Identification Records, Technical Laboratory, Uniform Crime Reports, and other services. ${ }^{119}$ The Bureau of Prisons of the Department of Justice has led efforts to improve local penal institutions; it advises state prison authorities, formulates minimum standards, conducts inspections and surveys, etc. ${ }^{120}$ The Criminal Division, too, can help reestablish effective and responsible local law enforcement not only by intelligent restraint in invoking federal criminal jurisdiction but more positively by developing and sponsoring uniform criminal legislation, procedural reforms, aids for indigent defendants, interstate compacts to facilitate apprehension of fugitives, and perhaps even personnel standards covering selection, tenure, and compensation, which will strengthen the independence of, and public confidence in, the quasi-judicial office of the prosecutor.

120 See Rep. ATT'y GeN. 192 et seq. (1941).

320 See Anv. Rep. Federal Bureau of Prisons 37 et seq (i946). 